\title{
Global Financial Crisis and the Nigerian Capital Market
}

\section{Chidinma Chioma B. George-Anokwuru ${ }^{1^{*}}$ \& Joseph Bidemi Obayori ${ }^{2}$}

\author{
${ }^{1}$ Department of Economics, Faculty of Social Sciences, University of Port Harcourt, Nigeria \\ ${ }^{2}$ Department of Economics, Faculty of Social Sciences, Nnamdi Azikiwe University, Awka, Nigeria \\ *Corresponding email: chiomanwoga@yahoo.com \\ https://riiopenjournals.com/index.php/finance-economics-review/index
}

Doi: https://doi.org/10.38157/finance-economics-review.v2i2.133

Citation: George-Anokwuru, C. C. B. \& Obayori, J. B. (2020). Global Financial Crisis and the Nigerian Capital Market. Finance \& Economics Review, 2(2), 27-38. Doi: https://doi.org/10.38157/finance-economics-review.v2i2.133

\section{Research Article}

\begin{abstract}
Purpose: This paper examined the impact of the global financial crisis on the capital market in Nigeria from 1980-2018. It specifically aimed to determine the impact of the currency crisis and liquidity crisis on the capital market in Nigeria.

Methods: The study was time series data based. Data were generated from the Central Bank of Nigeria Statistical Bulletin. The variables were subjected to descriptive statistics and the 'Augmented DickeyFuller' (ADF) unit root test prior to the 'Auto-Regressive Distributed Lag' (ARDL) model.

Results: The outcome of descriptive statistics demonstrated that the parameters were not normally distributed. Also, the ADF unit root test demonstrated that one of the parameters was stationary at $I(0)$ while the remaining two were stationary at I(1). Based on the ARDL results, it was observed that in the short run, the financial crisis has an indirect influence on the performance of Nigerian capital markets. Liquidity crisis, a proxy for the depletion of external reserves has a strong influence on the capital market. The long-run result showed that there is a long-run association amongst the variables.

Implications: In view of these findings, the paper recommends that the government should fine-tune its policy mix to ensure that the capital market and the economy do not suffer from the global economic crisis as it takes place.
\end{abstract}

Keywords: Global, Financial, Crisis, Capital Market, Bank Consolidation.

\section{Introduction}

The term financial crisis describes an array of conditions when certain financial institutions suddenly mislay an enormous component of their worth. In the 19th and 20th eras, a number of economic crises were interconnected with banking horrors, the decline in the stock market and the bursting of other financial effervesces and currency crises. Some of the identified financial crises are; banking crises, credit frictions, and market freezes, currency crises, and foreign debt crises (Ujunwa, Salami \& Umar, 2011). Some theories that elucidated economic crunches include the "World-systems theory" which described 
the perils that popular industrial countries will sometime face after prolong economic cycle, which began at the end of the 1973 oil crisis. When this happens, it often leads to a fall in the indicator of one of the drivers of the economy referred to as the "capital market". According to Sere-Ejembi (2008), the transmission channel of the global financial crisis is the capital market via the stock market. This is because it's an avenue where national economies receive foreign capital flows. Thus, the "capital market is the market where medium and long terms finance can be raised and equally provides diverse financial mechanisms that assist economic agents to pool, price and exchange risk" Osaze, 2009). By means of assets with pretty profits, it inspires saving in the financial form which is vital for administration and other related organizations that need long term funds (Jhingan, 2013).

Meanwhile, the world has been going through severe economic and financial emergency or crisis over the $19^{\text {th }}$ and $20^{\text {th }}$ centuries. Nigeria as an emerging nation was plagued with the heaviness of this emergency during the secondary impact, regularly alluded to an unexpected impact. This was inevitable by bunches of emerging nations because of the current progression caused by the existing liberalization occasioned by the healthy globalization of the universe. The world's economies are intertwined so that few economies could be influenced through the global transaction. Be that as it may, the emerging nations additionally rely upon industrialized nations for settlement, official advancement help, and FDI. These are the medium through which the worldwide financial crises are passed to emerging nations like Nigeria.

Prior to the 2007-2009 crisis, Nigeria has set out on some formative projects, such as the 1986 Structural Adjustment Programs (SAP), the 2005 bank capitalization policy wherein the Central Bank of Nigeria effected the deposit banks capitalization strategy of convincing banks to have a base capital base of 25 billion nairas so as to place the money related part on a decent way if there should arise an occurrence of an emergency. This measure to a large extent saved the financial sector from total collapse, however, its impact is still felt in certain segments to date (CBN, 2009). Given this, many public commentators and economists' analysts believed that the 2007 financial crisis was an awful beginning of another "great depression". This expression of fear inspired a speedy alleviation procedure of brisk recuperation of the United States of America as well as the world economy. In any case, this emergency influences all the parts of the Nigerian economy. For example, the Nigerian external sector which was exceptionally solid before the emergency disintegrated. Additionally, the rate of exchange of the Nigerian naira to the various monetary standards on the planet particularly the US dollar remained incredibly unpredictable. Oil prices on which the Nigeria budget is usually gauge have gone down because of the diminished interest of oil products in the worldwide market since consuming countries are attempting to cut the utilization of the items that greater part of the spending because of the money related emergency or crisis. Due to the reduced demand for oil in the global market, the level of revenue that was streaming into the monoculture economy of Nigeria started dwindling. The Nigerian Stock exchange was hutted by the crisis, as foreign investors, who realized the danger of financial turmoil, withdrew their foreign hedge funds back to their nations and this depressed the stock market.

Meanwhile, in the period of this extreme financial crisis, the CBN ought to serve as a buffer to the economy by injecting more cash in order to stem the tide. But rather than cash injections to increase liquidity in the financial system in order to spur economic growth, the Central Bank of Nigeria was rather "campaigning that investor should not fear, because the Nigerian financial system is insulated 
from the global financial crisis" (Soludo, 2008; Soludo, 2009). This significantly affected the confidence of investors have in the Nigerian capital market as it has become difficult for business organizations to raise new funds through the capital market. Also, some unethical behaviors such as price-fixing and overvaluation of shares among the market actors skipped intensely on the capital market and affected the economy adversely (Oluseyi, 2008). Based on the above problems, the objectives of the paper were to; examine the impact of the currency crisis on in terms of exchange rate the Nigerian capital market; and examine the impact of liquidity crisis in terms of reserve depletion on the Nigerian capital market.

\section{Literature Review}

There is a quantum of theories that describes the financial crisis, most of which was postulated based on the economic cycle proposition of both the classical and the Keynesian economists. Accordingly, Adam Smith (1776) in his "invisible hand and economic crisis" argued that free activity of powers in decentralized markets would lead not to disarray, given the fact that allocation of scarce resources would be effectively utilized to produce commodities needed by the society at the expense of unneeded ones. At such, Adam Smith contended that the market would consistently manage itself, with the end goal that there could never be a circumstance of downturn nor emergency. Thus, there is no requirement for government mediation as the question of failure in the market would not come to fore. Meanwhile, Keynes' (1936) hypothesis of market clearance and government mediation was the reaction to the classical view following the "great depression of the 1930s". Keynes tested the classics conventional theory by expressing that the market would not generally deal with itself and along these lines presented the requirement for government mediation each time the market fizzles (fails).

Keynes is of the view that the market framework works in an element of cycles after some time with the end goal that there are boom and downturns, subsequently presenting the idea of the Business cycles. His business cycle theory defines four faces in the long run, made up of boom, depression, downturn, and recuperation times. Thus, the year 2007, 2008, and 2009 crisis which has continued to date can be conceived to just another downturn that occurred after a decade of boom economic activities as was evident in most developing countries like Nigeria. Keynes' "general theory" gave a fundamental function to speculation choice in determining the degree of real demand, which in turn is the essential element in attaining the equilibrium level of employment and output.

Empirically, numerous scholars have used one method or the other to analyze the nexuses between financial crisis and growth. For instance, the World Bank (2019) examined bank regulations and supervision a decade after the global financial crisis. The report showed that market discipline, regulation, supervision, and reopened significant policy discussions are the necessary ingredients to avert a global financial crisis and bank distress. Also, Nelson, Onduka, and Yebimodei (2018) utilized OLS to inspect the effect of the global financial crisis on stock market output in Nigerian beginning from 2008-2016. They uncovered that the rate of exchange has no critical effect on the securities exchange. FDI has a positive however inconsequential effect on the Nigerian financial exchange and reserves have a negative yet immaterial effect on the Nigerian securities exchange. Olatunji and Weihang (2017) used descriptive techniques to examine the effect of policy analysis of the global financial crisis on the Nigerian economy. They observed that the CBN has achieved a high level of implementation policy to constraint complications and widespread of the global financial crisis in the economy in the present and

29 Published by Research \& Innovation Initiative, 3112 Jarvis Ave, Warren, MI 48091, USA 
future by injecting liquidity into the financial system. Njiforti (2015) studied the 2007/2008 global financial crisis and the Nigerian capital market from 2006-2009 with the use of VECM. The author found that the global financial crisis adversely and significantly affected the Nigerian capital market both in the short run and long run. Also, Ngwube and Ogbuagu (2014) examine the global financial crisis and the Nigerian Economy. The paper summarizes that the crisis creates an avenue to move more quickly to address outstanding reforms in areas such as financial regulation and inclusion, trade competition, and public sector improvement in the Nigerian economy.

Jenrola and Daisi (2012) examined the causes and ramifications of the global monetary emergency on the Nigerian banks. They utilized supplementary information base on four banks found in Ilorin city and utilized the Ordinary Least Square method. They opined that global monetary emergency indirectly affects the output of Nigerian banks regardless of the high liquidity controlled by these banks after the consolidation exercise of 2005. Ekine (2011) analyzed the impacts of the financial crisis on poor nations. He averred that more individuals will fall into neediness and become food uncertain because of the financial emergency problem. Over the long haul, there are solid signs that the worldwide food framework is in a general sense changing in various measurements. Trade security has equally reemerged, but have improved investments in the agricultural sector. Tella (2011) used OLS to analyze the effect of global money related crises on the Nigerian stock trade. He found that the global money related crisis has no huge impact on the Nigerian stock trade.

Udeme and Onuba (2009) utilized a unique processable general harmony model to assess the effect of the global downturn and the administration's palliative packages on China's economic development. Their results proposed that the GDP development rate in 2009 dropped to $2.9 \%$ because of the sharp drop in export of fabricated products, while the agricultural sector is more crisis-flexible. Mtango (2008) estimated the impact of the global economic crisis on African GDP during 2009-2010, with the aid of reduced-form equations. The paper used data on the distribution of migrants from Africa, GDP growth forecasts for host countries. The outcome demonstrated that remittance declines between 3\% \& $14 \%$ in African countries, with migrants to Europe hardest hit, while migrants inside Africa was moderately unaffected by the crisis. The projected impact on output for fairly remittance-depending countries is 2percent for the year 2009 but will short-lived, as a rise in host country income was anticipated for the year 2010.

Meanwhile, existing empirical studies revealed that a few studies had examined the effect of the financial crisis on the performance of an economy over different data periods. Also, from the empirical review, most of the studies of particular interest applied different estimation techniques in their analysis, such as Ordinary Least Squares, cointegration, and error correction technique. But these studies reached different conclusions about the influence of the global financial crisis on economic fundamentals, which cannot be generalized for policy decisions. But from the scholarship, it was realized that research works on the effect of the global financial crisis on the Nigerian capital market were scarce; this study filled this research gap. This was done by using the technique of autoregressive distributed lag (ARDL) model and as well extends the period of study to 2018 in order to capture the current realities in Nigeria. Thus, the study is of great importance as it provides a detailed analysis of the major effects of the global financial crisis in the Nigeria Capital market and as well serves as a source of raw materials further research on the global financial crisis and the Nigerian capital market. 


\subsection{The Meltdown of the Nigerian Capital Market}

As indicated by Gbosi (2009), the year 2008-2009 financial downturn which crashes the Nigerian capital market has been uncommon in its memorable development since 1960. Its market capitalization has plunged from an unequaled high of 13.5 trillion in March 2008 to not as much as 4.6 trillion constantly seven day stretch of January 2009. Moreover, the All-Share Index (a proportion of the size and heading of general value development) has additionally plunged from around 66000 basis points to under 22000points in a similar period. The stock prices encountered a free-for-all downward movement regime with over $60 \%$. Some of the various reasons for the meltdown are;

Global Phenomenon: The collapse of the world economy has not exempted the Nigerian capital market from the meltdown. This is because many developed economies stock markets such as the USA to Britain, Japan, Russia, France, and others are in serious trouble. Thus, as the world interacts through trade, it is very evident that any development in any part of the world affects other parts as well. Consequently, the Nigerian capital market is not shielded from this universal threatening financial disease.

The exit of Foreign Investors: Exit of international investors from the domestic economy is one of the causes of incessant fall of the Nigerian stock market. Many foreign investors that already have troubles in their domestic economies pulled out of the Nigerian stock market resulting in abandoning shares more than the capacity of domestic investors. As a consequence of this, the supply of equities overcame demand, resulting in price fall. According to a report from NSE (2009), purchase by foreign investors during the year 2007 which stood at $\$ 256$ billion declined to 150.135 billion in 2008; representing $6.3 \%$ of the total turnover. Concurrently, total sales during the year were more than $\$ 556.93$ billion, culminating in a net outflow of about 406.8 billion.

Failure of the Federal Government to Design a Bailout Plan: The incompetence of the Federal Government to mediate directly in the capital market which it sees as a purely private affair was one of the banes that cause a crisis in the capital market. Nigeria's government lacked the perception to examine the socio-economic consequences and series effects of a failed capital market. It, therefore, became impotent of hatching a bailout plan for its struggling capital market unlike the governments of developed nations like the USA, Britain, and France.

Structural Deficiencies of the Nigerian Stock Market: The inadequacies of the Nigerian capital market, especially the absence of market makers is another striking factor that caused the crisis in the Nigerian capital market. This is because, before the ending of January 2009, the Nigerian Securities and Exchange Commission has registered five market makers, but the Nigerian Stock Exchange was yet to also permit them due to preventable administrative setback. Thus, there are no functional market makers that can provide exit windows for investors who wish to check out.

\section{Methodology}

The type of data required for this study is the time series of data. Data sourced from the publication of Central Bank of Nigeria (CBN) statistical bulletin from 1980-2018. Such data 
include; Nigerian capital market - measured by market capitalization, currency crisis - measure by the foreign exchange rate, and liquidity crisis measured by the external reserve. The econometric technique of the Auto-Regressive Distribution Lag (ARDL) model was used to analyze the data. The technique of ARDL became necessary because of the order of stationarity of the series at the level and first difference. Meanwhile, both the descriptive statistics and the unit root test preceded the ARDL technique in order to establish both the features and stability of the data.

\subsection{Model Specification}

The empirical model for the study was cast in line with the model proposed by Nelson, Onduka, and Yebimodei (2018), who examined the global financial crisis and the stock market in Nigeria between 2008 and 2016. Their OLS model was in the form of SM =f(EX, FD, RS) $(1)$.

Where SM is the stock market, EX, is the exchange rate, RS is reserved and FD is foreign direct investment. But the current model dropped FD in the model as a result of the fact that it does not affect the performance of the stock market over the studied period. It also extends the time frame to 2018 which is more current than 2016. Thus, the study specified the functional and econometric form of the ARDL model thus;

$\mathrm{CPM}=\mathrm{f}(\mathrm{CRI}, \mathrm{LCI})$

Consequently, to put the variables on the same scale, the econometric form of the model was stated in the log-linear form of the ARDL cointegration and ECM model as follows:

$$
\begin{aligned}
& \Delta \mathrm{LnCPMt}=\alpha 0+\mathrm{a} 1 \mathrm{LnCPMt}+\alpha 2 \operatorname{LnCRIt}+\alpha 3 \operatorname{LnLCIt}+\sum_{i=1}^{n} \Delta \alpha 1 \operatorname{LnCPMt}-1+ \\
& \sum_{i=1}^{n} \Delta \alpha 2 \operatorname{Ln} C R I t-1+\sum_{i=1}^{n} \Delta \alpha 3 \operatorname{Ln} L C I t-1+\Omega E C M+\varepsilon \mathrm{t}
\end{aligned}
$$

Where; CPM is Capital market, CRI is a Currency crisis, LCI is a Liquidity crisis, $\alpha_{\mathrm{o}}$ is a constant term, $\alpha_{1}-\alpha_{3}$ is short-run dynamic coefficients of the regressors, $\Delta$ is first difference operator, $n$ maximum lag lengths, $\sum$ is the summation, ECM is error correction term lagged for a period, $\Omega$ is coefficient of error correction term, Ln is natural logarithm and $\mathscr{E}$ t is the white noise.

\subsection{Description of Variables and Sources}

Capital Market: Capital market is where medium and long terms funds can be raised. The capital market offers an assortment of monetary instruments that empower financial specialists to pool, cost, and trade risk. Thus, a well-financed stock market enhances the production capacity of an economy. The data was obtained from CBN statistical bulletin Volume 29, December 2018.

Currency Crisis: Cash crisis occurs when the national rate of exchange is speculatively been attack, bringing about the sharp devaluation of a floating currency. Usually, a currency crisis 
involves domestic monetary authorities losing a large number of their international reserves (Baker, 2008).

Liquidity Crisis: This type of crisis arises when one or more countries find that that they are unable to keep up the interest payment on their foreign debt. This situation may trigger a loss of confidence in the economy or the government, and so could bring about a currency or banking crisis. The data was obtained from CBN statistical bulletin Volume 29, December 2018.

\section{Results and Discussion}

Table 1: Descriptive Statistics for Variables

\begin{tabular}{|cccc|}
\hline Measurement & CPM & CRI & LCI \\
\hline Mean & 3327.131 & 93.47667 & 903131.5 \\
\hline Std. Dev. & 4383.601 & 103.0861 & 1476547. \\
\hline Skewness & 0.821210 & 1.312174 & 2.224746 \\
\hline Kurtosis & 1.950405 & 4.420066 & 7.265837 \\
\hline Jarque-Bera & 6.173685 & 14.46866 & 61.74244 \\
\hline Probability & 0.045646 & 0.000721 & 0.000000 \\
\hline Observations & 39 & 39 & 39 \\
\hline
\end{tabular}

Note: $C P M=$ Capital market, $C R I=$ Currency crisis, and LCI= Liquidity crisis

Source: Author's Computation from E- view 10

The result reported in Table I showed that the capital market has an approximate mean of $\$ 3327$ billion with the corresponding standard deviation of $\$ 4384$ billion. Similarly, the currency crisis has an approximate mean of $\$ 93$ billion with the corresponding standard deviation of $¥ 103$ billion. The liquidity crisis has an approximate mean of $\$ 03132$ billion with the corresponding standard deviation of $\$ 1476547$ billion. The skewness test showed that all the variables are positively sloped. The probability of Jarque-Bera statistics showed that the null hypothesis of the variables was rejected. Thus, the variables were not normally distributed. More so, the kurtosis test showed that all the series have a large tail. In sum, the results of the descriptive statistics showed that the distributions are not normally distributed. This may have resulted from the problem of trended data. Thus, the need for unit root test to stabilize the series before further estimation.

Table 2 Result of Augmented Dickey-Fuller Unit Root Test at Level and First Difference

\begin{tabular}{|ccccccc|}
\hline Variables & $\begin{array}{c}\text { ADF @ } \\
\text { Level }\end{array}$ & $\begin{array}{c}\mathbf{5 \%} \text { Critical } \\
\text { Value }\end{array}$ & Decision & $\begin{array}{c}\text { ADF @ 1 } \\
\text { Diff }\end{array}$ & $\begin{array}{c}\mathbf{5 \%} \text { Critical } \\
\text { Value }\end{array}$ & Decision \\
\hline LCI & -2.9443 & -2.9411 & Stationary I $(0)$ & & & $1(0)$ \\
\hline CRI & 0.6045 & -2.9411 & Not stationary & -6.1577 & -2.9434 & Stationary I(I) \\
\hline CPM & -0.8571 & -2.9411 & Not stationary & -6.2777 & -2.9458 & Stationary I(I) \\
\hline
\end{tabular}

Note: $C P M=$ Capital market, $C R I=$ Currency crisis, and LCI= Liquidity crisis

Source: Author's Computation from E- view 10

The ADF unit root test of stationarity result presented above showed that only the liquidity crisis (LCI) was stationary at order zero (at level). The non-stationary variables (CPM and CRI) 
were differenced once and it became stationary at first difference prior to estimations of the ARDL to prevent false regressions results.

Table 3 ARDL Bounds Test for Co-integration/Long Run Coefficients of the Model

\begin{tabular}{|cccc|}
\hline \multicolumn{2}{|c}{ Model (CPM, CRI, LCI) } & F-Statistic $=6.0092$ & K=2 \\
\hline 5\% Critical Values & Lower Bound=3.79 & Upper Bound=4.85 & \\
\hline Variables & Coefficient & t-statistics & P-value \\
\hline Ln(CRI) & 0.646691 & 1.641289 & 0.1102 \\
\hline Ln(LCI) & 0.571812 & 1.907498 & 0.0652 \\
\hline C & -1.774785 & -0.800063 & 0.4294 \\
\hline
\end{tabular}

Note: $C P M=$ Capital market, $C R I=$ Currency crisis, and LCI= Liquidity crisis

Source: Author's Computation from E- view 10

The ARDL bound test result presented in Table 3 showed that there is a long-run relationship amongst the variables (CRI and LCI). This is because the computed F-statistic of about 6.0092 is higher than both the upper and lower critical bounds of 4.85 and 3.79 respectively at $5 \%$ critical value. Therefore, the null hypothesis of no co-integration at a 5\% significance level for the model was rejected. Moreover, the coefficient of the two independent variables was positively signed but not statistically significant with the dependent variable. Thus, there is a long-run association amongst the variables. What the long-run result suggested is that both currency and liquidity crises will move together over a long period of time to affect the efficiency of the capital market in Nigeria.

Table 4: Discussion of Short Run ARDL Error Correction Model

\begin{tabular}{|cccc|}
\hline Variables & Coefficients & t-Statistic & P-Value \\
\hline $\mathrm{D}(\mathrm{CPM}(-1)$ & 0.841429 & 23.30696 & 0.0000 \\
\hline $\mathrm{D}(\mathrm{CRI})$ & -0.156374 & -1.249308 & 0.2203 \\
\hline $\mathrm{D}(\mathrm{LCI})$ & 0.090673 & 2.119912 & 0.0416 \\
\hline $\mathrm{ECM}(-1)$ & -0.158571 & -4.392286 & 0.0001 \\
\hline $\mathrm{R}^{2}=0.9945$ & $\mathrm{f}-\mathrm{stat}=1508$ & Prob(f-stat $)=0.0000$ & DW Stat $=1.8914$ \\
\hline
\end{tabular}

Note: $C P M=$ Capital market, $C R I=C u r r e n c y$ crisis, and LCI= Liquidity crisis

Source: Author's Computation from E- view 10

The results of the estimated model as presented in Table 4 showed that the R-squared is $99 \%$, this showed that the model is a good fit. The Durbin Watson (DW) test which measures the degree of serial autocorrelation in the estimated model has a value of 1.8914; which is value is very close to $2.0 \mathrm{DW}$ benchmark, thus, the study infers that there is no problem of serial autocorrelation. Thus, the estimated model is valid for policymaking. Furthermore, the result of the short-run dynamic showed that the coefficient of the error correction term has the hypothesized negative sign (-0.158571) and statistically significant at a 5\% conventional level. This indicated that the dynamic model has about $16 \%$ speed of adjustment. In the meantime, 
the estimated results also showed that, in the short run, the coefficient of lag one value of the capital market (CPM) is positively related to the current value of CPM and statistically significant at 5\% level. Similarly, the regression coefficient of a liquidity crisis (LCI) has a positive but significant relationship with the capital market. Thus, an increase in liquidity crisis will significantly affect the growth of the capital market. What this suggests is that as liquidity crisis arises due to the depletion of foreign reserves, the Nigerian capital market feels the impact in the period of study.

Meanwhile, the regression coefficient of the currency crisis (CRI) has a negative but insignificant relationship with the capital market. Thus, an increase in currency crisis brought about by the weak value of the naira to international currencies such as dollar and Pounds will cause a corresponding decrease in the capital market. The finding implies that the global financial crisis will affect the Nigerian capital market negatively since Nigeria naira has a weak relationship with the international currencies. Thus, it will require a huge sum of Nigeria naira to purchase foreign currencies. The finding is supported by the empirical work of Tella (2011), who averred that the global financial crisis has no significant effect on the Nigerian stock exchange. Also, Mtango (2008) in his study on the impacts of the international crisis on the South African economy; opined an inverse relationship between the international crisis and the economy.

In sum, the short-run ARDL results displayed that the financial crisis has an indirect influence on the performance of the Nigerian capital markets. Also, the liquidity crisis has a significant influence on the capital market. Thus, the result suggested that within the period of both currency and liquidity crises, the Nigerian capital market was hard hit. This scenario, therefore, necessitated the sluggish performance of the capital market during the brief period of the global financial crisis.

\section{Post Estimation Test}

This section helps to validate the ARDL results in order to ascertain the usefulness of the estimated model for policymaking.

Table 5. Serial Correlation and Heterescedasticity Tests

\begin{tabular}{|cccc|}
\hline Test Type & Test Stat. & p-value & Critical Value \\
\hline Serial Correlation (Breusch-Godfrey LM Test) & Chi-Square $\left(X^{2}\right)$ & 0.0588 & 0.05 \\
\hline Heteroscedasticity (Breusch-Pagan-Godfrey) & Chi-Square $\left(X^{2}\right)$ & 0.4485 & 0.05 \\
\hline Stability (Ramsey Reset Test) & & & \\
\hline
\end{tabular}

Source: Authors' Computation from E-view 10

Table 5 showed that in the estimated ARDL model, serial autocorrelation is not a problem as a result of the fact that chi-square $\left(\mathrm{X}^{2}\right)$ probability values of 0.0588 exceed the 0.05 critical value. Thus, the null hypothesis of no serial autocorrelation was upheld. Similarly, the Autoregressive 
Conditional Heteroskedasticity $(\mathrm{ARCH})$ result showed that in the model, heteroskedasticity is not a problem as a result of the fact that the Chi-square p-value of 0.4485 is greater than the $5 \%$ convectional p-value. Meaning that the variance of the residual is constant over the sampled period. Also, the stability test via Ramsey reset test with a p-value of 0.9110 , showed that the estimated coefficient is stable. Thus, the result indicated acceptance of the null hypothesis that confirm the stability of the estimated ARDL.

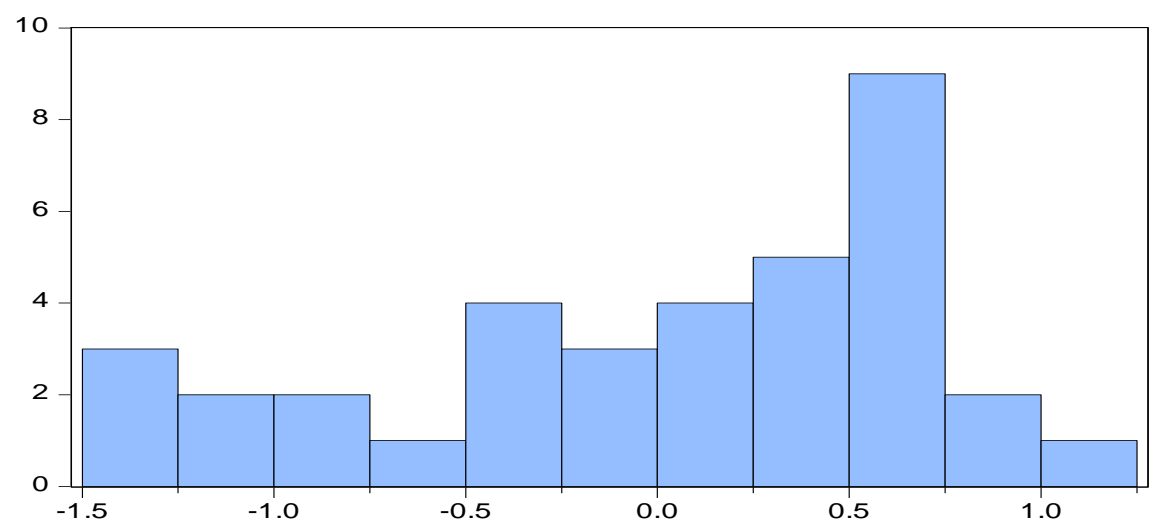

\begin{tabular}{|lc|}
\hline \multicolumn{2}{|l|}{ Series: Residuals } \\
Sample 1982 2017 \\
Observations 36 \\
Mean & $4.97 e-16$ \\
Median & 0.203796 \\
Maximum & 1.152977 \\
Minimum & -1.410474 \\
Std. Dev. & 0.720349 \\
Skewness & -0.635939 \\
Kurtosis & 2.266691 \\
& \\
Jarque-Bera & 3.233120 \\
Probability & 0.198581 \\
\hline
\end{tabular}

Figure 1: Normality Test

The normality test as shown in Figure 1 showed that the error term is normally distributed. This is because the probability value of the Jerque-Bera statistic (J-B stat) which is 0.1985 is greater than 0.05 critical value. Thus, it was concluded that the sample data fit a standard normal distribution. From the post estimation presented in Table 5 and Figure 1, the statistical criteria and reliability of the estimated model were authenticated. Thus, the model is good for policy formulation.

\section{Conclusion and Recommendations}

The study examined the global financial crisis and the capital market in Nigeria from 1980-2018. This is because most developing countries witnessed a global financial crisis that culminated in a currency crisis and liquidity crisis which its spillover effects resulted in the loss of confidence in the financial sector and the long-run effect on the growth of the economy. This study has demonstrated that the Nigerian capital market is sensitive to shocks in the global financial crisis, given the negative impact of the currency crisis on the Nigerian capital market. Thus, the financial crisis hurts the performance of Nigerian capital markets despite the high liquidity possessed by this market immediately after the 2005 bank consolidation. Meanwhile, the empirical finding showed that liquidity crisis proxied by depletion of external reserves has a significant impact on the capital market despite the direct relationship with the capital market which does not conform to economic theory. Thus, it was concluded that the global financial crisis was a major problem in the capital markets during the period of study. Based on the findings, the study made the following recommendations; Government should fine-tune its policy mix to ensure that the capital market and economy, in general, do not suffer from a 
global crisis. The external reserve should be increase and maintain to serve as a buffer to the domestic economy during the global economic crisis.

\section{Authors' Contribution: Chidinma Chioma B. George-Anokwuru and Joseph Bidemi Obayori} jointly contributed to the data collection, analysis and writing the article.

\section{Conflicts of Interest: The authors declare no conflict of interest.}

\section{REFERENCES}

Baker, Dean (2008). The Housing Bubble and the Financial Crisis. Center for Economic and Policy Research.

Central Bank of Nigeria (CBN, 2009). The current global financial crisis: Antecedents, causes, effects, and implications for the Nigerian economy.

Central Bank of Nigeria (2018). The Statistical Bulletin, 29, December 2018.

Ekine.N.T (2011). Macro-Economic Dimensions of Competitive Indicator and Policy Performance. Port Harcourt: Dominus Publishers.

Gbosi, A.N. (2009). Global Economic Meltdown and the Nigerian Financial System. Port Harcourt: Harley Publications Company.

Jenrola, A. \& Daisi, R. (2012).The implication of the global financial crisis on the Nigerian capital market performance: European Journal of Humanities and Social Sciences, 16(1) 803-819.

Jhingan, M.L. (2013). Macro-economic theory (12 th edition). Delhi: Vrinda Publisher Ltd.

Keynes, J.M. (1936). The General Theory of Employment, Interest and Money, London; Macmillan.

Mtango, E. (2008). African growth financial crisis and implications: Causes of economic meltdown in Nigeria.

Nelson J., Onduka K. \& Yebimodei, E. G. (2018). Impact of the global financial crisis on the Nigerian stock market performance, International Journal of Recent Advances in Multidisciplinary Research, 5(4), 3740-3754

Njiforti, P (2015). Impact of the 2007/2008 Global financial crisis on the stock market in Nigeria, CBN Journal of Applied Statistics, 6 (1a), 49-68

Ngwube, A \& Ogbuagu, M. (2014). The global financial crisis and Nigeria economy, Global Journal of Management and Business Research: B Economics and Commerce, 14(4)

Olatunji, J. \& Weihang, H. (2017).The effect and policy analysis of the global financial crisis on Nigeria Economy, International Journal of Management Science and Business Administration, 3(4), 58-64

Oluseyi, B. (2008). Averting financial crisis in Nigeria. Daily Punch Newspaper, $13^{\text {th }}$ November.

Osaze, E.B. (2009). Quo-Vadis Nigeria in the Global Financial Meltdown. Being A Paper Presented to the University of Ibadan Alumni Association, Edo State Branch at the University of Benin on $5^{\text {th }}$ December.

Sere-Ejembi A. A. (2008). The 2004 banking sector reform agenda: An evaluation. The Nigerian Economic Society (NES) Newsletter, 48(1).

Sere-Ejembi, A. A. (2008). Nigerian stock market reflection of the global financial square. Bauchi: Abubakar Tafawa Balewa University Press.

Soludo, C. (2008). Nigeria's Financial System Strategy 2020 Plan. Proceedings of the Financial System Strategy 2020 International Conference, Abuja, 18 th June 2008.

Soludo, C.C. (2009). Global Financial and Economic Crisis: How vulnerable is Nigeria.

Smith, A. (1776). The Wealth of Nations. Edwin Canaan (ed) (Reissued by Modern Library, New York) New York: Random House, Inc

Tella, S.A. (2009). The Global Economic Crisis and Nigerian Stock market: Issues on Contagion. Nigerian Journal of Securities and Finance, 14(1), 101-116.

Udeme, E. \&Onuba, I. (2009). Global Financial Crisis: Keeping the Nigerian Stock Market viable. Daily Punch Newspaper, $5^{\text {th }}$ January. 
Ujunwa, A., Salami, O.P. \& Umar, H.A. (2011). The Global Financial Crisis: Realities and Implication for the Nigerian Capital Market. American Journal of Social and Management Sciences, 2(3), 341-347.

World Bank (2019). Global Financial Development Report 2019/2020: Bank Regulation and Supervision a Decade after the Global Financial Crisis. Washington, DC: World Bank. doi:10.1596/978-1-4648-1447-1.

풍-

(C) 2020 by the authors. Licensee Research \& Innovation Initiative, Michigan, USA. This article is an open-access article distributed under the terms and conditions of the Creative Commons Attribution (CC BY) license (http://creativecommons.org/licenses/by/4.0/). 